renewed democracy. Chapter 5, "From Mandatory Employment to Unemployment," reveals some narrators appreciating pre-1989 job security and expressing anxiety about work and well-being under capitalism when "you're scared of losing your job" and there is "the terrible and ever widening gap between the rich and the poor" (141). Chapter 6, "The Meaning of Free Time: Work, Family, and Leisure," shows that Czechs frequently enjoyed life and felt content before 1989, although they also appreciate expanded post-socialist leisure offerings, including more foreign-travel opportunities. Chapter 7, "Us and Them," evaluates narrators' perceptions of elites before and after "the crack," with post-socialist political and economic leaders criticized for corruption, self-enrichment and, to quote from one interview, the perpetuation of "a situation where people would rather keep their mouths shut, and as I said, they put blinders on and keep going" (197).

Two appendices appear at the book's end. One discusses the documentary photographer Jindřich Štreit, the creator of images in the volume of ordinary people during state socialism. The other lists all narrators with brief biographies. An appendix reproducing questions guiding the interviews could be helpful for readers wishing to learn more about oral-history methodologies. One expects better editing from Oxford University Press. The book's main conclusions will not be new to experts in Czech history, although the evidentiary base is novel and important. The voices and memories that Vaněk and Mücke so carefully heard and preserved give this work a rare and special human multi-dimensionality, and enhance appreciation of oral history and non-tangible heritage.

Cathleen M. Giustino Auburn University

\title{
Whose Memory? Which Future? Remembering Ethnic Cleansing and Lost Cultural Diversity in Eastern, Central and Southeastern Europe. Ed. Barbara Törnquist-Plewa. Studies in Contemporary European History, Vol. 18. New York: Berghahn Books, 2016. viii, 233 pp. Notes. Bibliography. Index. Illustrations. Photographs. \$95.00, hard bound.
}

doi: 10.1017/slr.2017.208

The edited volume Whose Memory? Which Future? is comprised of seven chapters that theorize the formation of collective memory about mass violence in eastern, central, and southeastern Europe, with an excellent introduction and concluding chapter by volume editor Barbara Törnquist-Plewa. The book grew out from a research project at Lund University, enabling relatively consistent analysis of six different cases from Poland, the Czech Republic, Ukraine, Croatia, and Bosnia.

The book itself is the best argument in favor of comparative work in memory studies. The same research question, namely "how does the present day population relate to the memory of ethnic cleansing and the cultural heritage of the people that vanished?" (4), was addressed using different methods, sources, and disciplines, revealing complex memory dynamics vis-à-vis the Second World War (with the exception of Bosnia case). The research project's multidisciplinarity is an advantage rather than weakness of the book. It enables the reader to critically examine comparative advantages of different approaches, for example participant observation, skillfully used by Dragan Nikolić. It also provides a more intimate understanding of memory activism in Višegrad, compared to interviews with Wroclaw's inhabitants, which enable an insight into dynamics between individual and collective memory formation. Similarly, use of different sources such as urban landscapes, historiographical 
texts, tourist guides, and local and national newspapers in Tea Sindbæk Andersen's exceptional article on the memory of Zaratinis in Zadar, enables differentiation between micro changes and layered identities that might have been overlooked by a more state-centered research approach. In other chapters, carefully examined cases show alliances, cooperation, and confrontations between the actors on different levels (international, transnational, national, local), contextualizing the creation of collective memory within globalization and Europeanization processes. Tomas Sniegon's outstanding comparison of monuments, locations, memory actors, and their intentions in erecting four memorials to Sudeten Germans in the Czech Republic exemplifies the importance of detailed examination in each case, showing how subtle the dissonances in memory production might be.

One of the most intriguing results of the comparison is the prevailing reluctance to acknowledge the mass atrocities as moral wrongs, something shared to a different degree by all current majority populations. Despite the liberalization of public space in post-communist countries, the inclusion of victims' memories remains on the level of proclamation, while the justification of violence remains intact, whether as "deserved destiny" (221) or "rightful anger of the harassed citizens" (66). Public discourse remains persistently lacking in genuine empathy for victims. Simultaneously, the passage of time and the generational shift has produced some change-the hegemonic communist narrative has been challenged, new memory practices have been established, but argumentation schemes justifying violence seem to have been inherited from the hegemonic narrative. In comparison with more recent conflict and memory activism in Višegrad, where hegemonic narratives are still strongly defended, it might be asked to what extent the "other" as perceived threat consolidates hegemonic narratives, a question which was insufficiently addressed by the authors in the volume.

All the chapters share an assumption of western Europe as normative power, which sets values and norms for memory activism on the one hand, and as political power that can accelerate if not initiate memory activism, on the other. Normative order is interpreted based on the request to acknowledge responsibility for mass violations of human rights and include the victims' memory in current memory practices, referring to Jeffrey Olick's "Politics of Regret" as reconciliation narrative, or even cosmopolitan attitudes and identification as part of memory politics pursued by international organizations like the European Union (EU), UNESCO, and others. According to the editor, the main aim of the book was "to contribute to more ethical approaches in discussions on how Europe should remember its difficult past" (11).

Several chapters show how recovering or discovering the prewar "Germanness" of east European cities served as a means to recontextualize east European cities as historically western, pointing out the importance of city branding and the so-called Heimat tourism as motivation and goal for memory activism. As noted by Niklas Bernsand, minorities like Belarusians or Azeris remain excluded from multicultural narratives in Chernivtsi, despite the fact that their communities are more numerous than Germans or Jews (122). This seems to prove that the usefulness of the past for the future, rather than moral considerations, play highly significant roles in memory politics.

In the final chapter, Barbara Törnquist-Plewa uses three of the four types of memory activism developed by Michael Bernhard and Jan Kubik (Twenty Years after Communism: The Politics of Memory and Commemoration, 2014), namely mnemonic warriors, mnemonic pluralists, and mnemonic abnegators, to interpret memory activism presented in the studies. She concludes that abnegators remain dominant in Zadar (Croatia) and Višegrad (Bosnia), while the dismantling of the homogenic narrative appeared in four sites of Czech memory, Wroclaw (Poland), and L'viv (Ukraine), where more mnemonic pluralists actively engage in the memory scene. Although 
neither of these cases present a clear-cut difference between types of actors, the most confusing is the case of Chernivtsi (Ukraine), where all three types operate and overlap. Despite this mnemonic pluralism, Törnquist-Plewa questions if these practices exemplify cosmopolitan, internalized values such as human rights and respect for all human life, as promoted by international and transnational actors, or if they remain subjected to ethnic-nationalism, paying lip-service to EU integration or pragmatically using EU funds for the creation of a new positive self-image.

In conclusion, it might be said that the book can be seen as an invitation, or rather urgent request, to engage more in comparative memory research on the one hand, and to reflect on the possibility of shared European memory politics, on the other. The book is not only highly informative and meticulously researched but also intellectually engaging and provocative. Tacit assumptions that reconciliation as a part of cosmopolitanism already figure as shared normative frames in Europe require better understanding of European memory politics and particularly ethnic-nationalist memory within the EU. The volume demonstrates the use of memory as usable past, but also shows that there are limits to the pragmatic exploration of the past, and that further comparative research of these limits might provide much needed understanding of contradicting forces driving memory creation in Europe today.

KATARINA RISTIĆ Helmut-Schmidt-University University of the Federal Armed Forces Hamburg

Writers and Rebels: The Literature of Insurgency in the Caucasus. By Rebecca Gould. New Haven: Yale University Press, 2016. xi, 336 pp. Appendix. Notes. Bibliography. Glossary. Index. Photographs. Maps. \$85.00, hard bound. doi: 10.1017/slr.2017.209

Chechnia's shahidki, women who commit acts of terrorism against the Russian state and the Russian population, have become notorious. Used to justify draconian retribution against the peoples of the North Caucasus, these female suicide bombers sacrifice their lives despite knowing that their acts are unlikely to bring down the Russian state. Why then, do these women blow themselves up? In Writers and Rebels, Rebecca Gould uses close textual analyses of Chechen, Daghestani, Georgian, Ossetian, and Russian literature to link the figure of the abrek, the infamous bandit of the Caucasus, to the shahidka. In doing so, she explains the logic of what she calls "transgressive sanctity," a postcolonial formation in which violating the law of the colonizer becomes a sacred form of action. Working through three languages and six cultures, Gould has produced a linguistic and theoretical tour de force whose argument transcends the post-Soviet sphere to address the form of violence characteristic of the contemporary moment.

In an innovative move, Gould uses literature and ethnography, rather than the historical record, to interrogate culture and ethics. She begins by examining the figure of the abrek, particularly in the person of Imam Shamil, the legendary Caucasian guerrilla fighter who led the resistance against Russian occupation between 1832 and 1859 . She argues that once the abrek transgressed the law to oppose a sovereign power seen as illegitimate, he became more than just a bandit, but someone who made violence a sacred act. Gould labels this valorized illegality "transgressive sanctity," showing how anticolonial violence became culturally meaningful in the Caucasus.

Gould could have let the abrek stand in for all the peoples of the Caucasus. But she goes even further, showing how the Chechen logic of opposition was muted and 